NBER WORKING PAPER SERIES

\title{
MONETARY UNIONS, EXTERNAL SHOCKS AND ECONOMIC PERFORMANCE: A LATIN AMERICAN PERSPECTIVE
}

\author{
Sebastian Edwards \\ Working Paper 12229 \\ http://www.nber.org/papers/w12229 \\ NATIONAL BUREAU OF ECONOMIC RESEARCH \\ 1050 Massachusetts Avenue \\ Cambridge, MA 02138
}

May 2006

This is a revised version of a paper presented at the International Workshop on "Regional and International Currency Arrangements," organized by the Bank of Greece and the Oesterreichische Nationalbank, February $24-25,2006$, Vienna. I thank Roberto Alvarez for his assistance. The views expressed herein are those of the author(s) and do not necessarily reflect the views of the National Bureau of Economic Research.

(C)2006 by Leonard Caruana and Hugh Rockoff. All rights reserved. Short sections of text, not to exceed two paragraphs, may be quoted without explicit permission provided that full credit, including (@) notice, is given to the source. 
Monetary Unions, External Shocks and Economic Performance: A Latin American Perspective Sebastian Edwards

NBER Working Paper No. 12229

May 2006

JEL No. F02, F43, O11

\begin{abstract}
During the last few years there has been a renewed analysis in currency unions as a form of monetary arrangement. This new interest has been largely triggered by the Euro experience. Scholars and policy makers have asked about the optimal number of currencies in the world economy. They have analyzed whether different countries satisfy the traditional "optimal currency area" criteria. These include, among other: (a) the synchronization of the business cycle; (b) the degree of factor mobility; and (c) the extent of trade and financial integration. In this paper I analyze the desirability of a monetary union from a Latin American perspective. First, I review the existing literature on the subject. Second, I use a large data set to analyze the evidence on economic performance in currency union countries. Iinvestigate these countries' performance on four dimensions: (a) whether countries without a national currency have a lower occurrence of "sudden stop" episodes; (b) whether they have a lower occurrence of "current account reversal" episodes; (c) what is their ability to absorb international terms of trade shocks; and (d) what is their ability to absorb "sudden stops" and "current account reversals" shocks. I find that belonging to a currency union has not lower the probability of facing a sudden stop or a current account reversal. I also find that external shocks have been amplified in currency union countries. The degree of amplification is particularly large when compared to flexible exchange rate countries.
\end{abstract}

Sebastian Edwards

UCLA Anderson Graduate School of Business

110 Westwood Plaza, Suite C508

Box 951481

Los Angeles, CA 90095-1481

and NBER

$\underline{\text { sebastian.edwards@anderson.ucla.edu }}$ 


\section{Introduction}

During the last few years there has been a renewed interest in analyzing the costs and benefits of monetary unions. To a large extent this interest has been the result of the launching of the Euro in January, 1999. Scholars, policy makers and analysts have asked what is the optimal number of currencies in the world. More specifically, they have asked whether it would make sense for some countries to give up their national currencies and either adopt another country's currency, or join other nations in creating a regional currency. The first option - adopting another country's currency - has generally been known as the "dollarization" question; the second option - creating a multi-nation currency - is known as the "independent currency union" question. ${ }^{1}$

At the end of the $19^{\text {th }}$ century the world had a relatively small number of currencies. There were a number of monetary unions - the two better known ones were the Latin Monetary Union and the Scandinavian Monetary Union --, and many countries and territories used other county's currency as legal tender. These arrangements were dictated both by political as well as by geographical and economic considerations. This is illustrated by the fact that the dependencies of Great Britain did not use exclusively sterling; they relied on a variety of currencies, including the U.S. dollar and the Indian Rupee (Muhleman, 1895).

Historically, the emergence of national currencies has been associated with political considerations and, in particular, with sovereignty. Indeed, one of the first measures newly independent countries took during the nineteenth and twentieth century was to establish their own national currencies. In his well-known article on optimal currency areas Mundell (1961) cited the following quote from John Stuart Mill:

"[A]lmost all independent nations choose to assert their nationality by having, to their own inconvenience and that of their neighbours, a currency of their own." (1894, p. 176).

\footnotetext{
1 "Dollarization" is used as a general term, even if the country were to adopt a currency other than the dollar, such as the Euro, or the Pound Sterling.
} 
It is perhaps for this political reason that, historically, in the Latin American nations there have been limited discussions on the creation of regional currencies. To be sure, some Latin American countries have become officially dollarized - Panama since 1903, Ecuador since 2000 and El Salvador, since 2001--, and some, including Argentina in the late 1990s and early 2000s have seriously considered dollarization. However, discussions on the creation of regional, or sub-regional, monies have never captured the imagination of Latin American politicians or scholars. In 1926, for example, there was a proposal to create a monetary union comprising Argentina, Chile, Uruguay and Paraguay. Although the supporters of this policy were prominent thinkers and politicians, and went as far as detailing the operational features of the union, there was very little political support for the idea. ${ }^{2}$ Proposals to create a monetary union in Central America, or the Andean countries or, more recently, in Mercosur have never been more than academic exercises. In a way this is surprising, since, at least in principle, certain groups of Latin American nations would seem to satisfy some of the basic criteria for an optimal currency $\operatorname{area}(\mathrm{OCA}) .^{3}$

During the last few years a number of papers on (potential) monetary unions around the world have been published. ${ }^{4}$ Most of these works have analyzed empirically whether particular groups of countries - including Latin American nations - satisfy the traditional and basic criteria for joining a monetary union. In particular, most of these studies have analyzed: (a) the synchronization of the business cycle across countries and with respect to major nations such as the U.S.; (b) the degree of factor mobility within the potential monetary union; (c) macroeconomic convergence among the possible union members; and (d) the extent of trade and financial integration in the countries that would potentially form a monetary union (see Section II of this paper for a detailed, and selective, review of works on OCA in Latin America). More recently, an important body of work has argued that the traditional OCA criteria are endogenous to the monetary regime. In particular, the degree of trade and financial integration will tend to increase in

\footnotetext{
${ }^{2}$ See Yañez, Bunge and Subercaseaux (1926). It is interesting to notice that this proposal did not include Brazil.

3 See, however, the review of works on the issue presented in Section II of this paper.

${ }^{4}$ See, for example, the papers published in volume 13(2002) of the North American Journal of Economics and Finance (as well as the literature cited in those papers).
} 
countries that share a common currency. ${ }^{5}$ In Table 1 I present a list of countries (and territories) with currency unions; this list includes both dollarized countries as well as countries that belong to independent currency unions.

The purpose of this paper is to analyze a number of issues related to monetary unions from a Latin American perspective. I take, however, a different perspective from that of most works on the subject. Instead of analyzing whether the Latin American countries satisfy the traditional OCA criteria, such as facing similar external shocks across countries, I analyze the empirical evidence on the economic performance of countries "without a currency of their own," and I interpret these results from the perspective of the Latin American nations. The empirical analysis presented in this paper is divided in two parts. First, I investigate whether belonging to a currency union reduces the probability of a country being subject to: (a) "sudden stops" of capital inflows; and/or (b) "current account reversals." Both of these are important questions, since the Latin American nations have traditionally been subject to significant fluctuations in capital flows, and have experienced a large number of current account crises (Edwards, 2004). Second, I analyze the ability of monetary union countries to accommodate three types of external shocks: (a) terms of trade shocks; (b) sudden stops of capital inflows; and (c) current account reversals. The question is whether, as opponents of monetary unions have argued, countries without a currency of their own incur in larger adjustment costs as a result of external shocks. Again, this is a highly relevant issue for the Latin American nations, since they have historically had highly volatile terms of trade, and have been subject to wide variations in external conditions (Edwards and Levy-Yeyati, 2005). In performing this analysis I use a new and large cross-country data set, and I control for the role of other relevant variables.

The rest of the paper is organized as follows: In Section II I review the literature on currency unions in Latin America. I show that the vast majority of these papers analyze whether the Latin Countries - or a subgroup of them - satisfy the OCA criteria. In Section III I use a new comparative data set to analyze economic performance in countries with currency unions, from a Latin American perspective. More specifically, I investigate whether countries without a currency of their own have a lower probability of

\footnotetext{
${ }^{5}$ See, for example, Frankel and Rose (1999) and Rose and Engel (2002).
} 
experiencing two type of shock that are common in Latin America - sudden stops of capital inflows and current account reversals. In performing this analysis I use randomeffect probit regressions on pooled data. In Section IV I analyze the way in which external disturbances affect real growth in countries with different monetary regimes. I present a model of the dynamics of GDP per capita growth, and I investigate whether the impact of external shocks on growth is different in countries without a currency of their own, or monetary union countries, and in countries with a national currency. Finally, in Section V I provide some concluding remarks, and a word of caution on how to interpret the empirical results presented in this paper. There is also a data appendix.

\section{Monetary Unions in Latin America}

In this section I discuss briefly and selectively the literature on currency unions in Latin America. I define a country as belonging to a currency union if it does not have a currency of its own, and uses a "common currency" with other countries. This "common currency" could be either another nation's currency (i.e. the U.S. dollar or the Euro) or it could be a regional currency. The section is divided in two parts: First, I briefly deal with the theoretical literature on optimal currency areas. In particular, I discuss what has come to be known as the "OCA criteria," or prerequisites for a country successfully joining a currency area. Second, I provide a brief review of the empirical literature on currency unions in Latin America.

\section{II.1 Optimal Currency Areas: Theory and Policy Criteria}

In his seminal 1961 paper Robert Mundell developed the modern theory of optimal currency areas. The main conclusion of his analysis was that "the optimum currency area is the region." By this, Mundell meant that when it comes to determining the scope of specific currency, the relevant entity is not a nation, but rather a region characterized by price and wage flexibility, factor mobility, trade integration and similar external shocks. He argued that the in North America there were two optimal currency areas: one corresponding to the eastern United States and Canada, and the other corresponding to the western U.S. and Canada.

Although Mudell's original contribution is not technical - indeed, there isn't a single equation or diagram in the paper --, he was very explicit in determining his 
optimality criteria. According to him, "[O]ptimality is here defined in terms of the ability to stabilize national employment and price levels' (Mundell 1961, p. 179). That is, his criterion is perfectly equivalent to minimizing a loss function on the square deviations of employment from its long term trend level, and of inflation from its target. In that sense, Mundell's criteria of optimality is consistent with that used in modern macroeconomic analyses.

Subsequent research attempted to make Mundell's theory operational, by developing a "checklist" of criteria that countries should satisfy in order to qualify as candidates for a (successful) currency union. ${ }^{6}$ Generally speaking, it was though that in countries than satisfied these criteria the benefits of joining a currency union exceeded the costs of doing so. Initially this "checklist" was restricted to the type of real and structural variables and factors emphasized by Mundell's original article. With time, a number of macroeconomic, political, institutional and monetary variables have been added to this checklist.

By now the list of OCA criteria, or main prerequisites for joining a currency union, has grown significantly. It may be summarized by the following " $O C A$ Decalogue": ${ }^{7}$

- Factor mobility, and in particular labor mobility, across the members of the potential union.

- High level of trade in goods across the members of the union.

- Different (or diversified) composition of output and trade across countries.

- Price and wage flexibility across members of the union.

- Similar inflation rates across countries.

- Financial markets should be integrated across countries.

- Absence of "fiscal dominance" in the individual countries.

- Low, and similar, levels of public sector debt in the different countries.

${ }_{7}^{6}$ Another two important early contributions are McKinnon (1963) and Kenen (1969),

7 See, for instance, Bayoumi (1994), Eichengreen and Bayoumi (1997), De Grauwe (2001) and Tavlas (1991, 1992). 
- Similarity (or synchronization) of external shocks to which the different countries are exposed to.

- Political coordination across countries.

The main point of this "Decalogue" is that if these conditions are met, the members of the union would not need to rely heavily on (bilateral) exchange rate changes when subject to external shocks. Countries that satisfy the Decalogue would have a reduced need for implementing "expenditure switching policies." Thus, for these countries the benefits of a currency union - in terms of enhanced credibility, lower transaction costs, and lower and more stable inflation - would exceed the (potential) costs of giving up the exchange rate as a policy tool. As Tavlas (1993) and Mongelli (2002), among others, have pointed out, such an extensive list of prerequisites introduces a number of practical policy problems. These include: (a) the need to establish a ranking of criteria according to their importance; and (b) how to deal with cases when a potential OCA member satisfies some of the criteria, while another potential member satisfies a different subset of them. The Euro zone, for instance, prioritized fiscal, monetary and financial considerations through the Maastricht Treatise. This, however, needs not be the case for other currency unions.

One of the costs of a belonging to a currency union is that member countries give up monetary independence. However, the extent to which monetary independence is actually lost will depend on the exact nature of the monetary union. If the country in question unilaterally adopts another nation's currency - as in the case of unilateral dollarization - monetary independence will be fully lost. Moreover, in this case, seignorage will also be lost. In Latin America, for example, this has been the case in Panama, Ecuador and El Salvador. ${ }^{8}$ If, on the other hand, a new common currency is adopted, monetary independence will only be lost partially. This is so because members of the union will be represented in the governance structure of the new common central bank, and, at least in principle, would have a say on how the common or regional central bank policies are determined.

\footnotetext{
${ }^{8}$ See Levy-Yeyati and Sturzenegger (2003).
} 
There are circumstances, however, when loosing monetary independence may not be a cost. This would be the case, for instance, if the country in question has historically abused this independence, and has generated very high levels of inflation. Indeed, under these circumstances giving up the national currency and joining a currency union is a way of "tying the policy makers' hands," and achieving credibility. This "credibility effect" of joining a monetary union - or more precisely, of joining a credible monetary union has been emphasized with respect to the Euro zone and the new EU members from Central and Eastern Europe. It has also been discussed in the Latin American context as one of the advantages of (unilateral) dollarization. This point was made by Dornbusch (2001), who argued that by achieving credibility, Latin American countries that dollarized would experience a decline in (real) interest rates, and, thus, higher investment and faster growth.

As a number of authors have argued, many of the criteria listed in the " $O C A$ Decalogue" listed above are endogenous to the monetary and exchange rate regime (Frankel and Rose, 1998). More specifically, (neighboring) countries that share a common currency will experience an increase in bilateral international trade in goods, a point forcefully made by Rose (2000), and Rose and Van Wincoop (2001), among others. Edwards (1999), and Powel and Sturzenegger (2003), on the other hand, have investigated the way in which the monetary regime affects interest rate behavior and the cost of capital, and have argued that a common currency will tend to increase the degree of financial integration. An implication of this endogeneity argument is that the "OCA Decalogue" should be analyzed in a forward-looking fashion, trying to determine what would be the effect of adopting a common currency on many of these variables and criteria once the union is implemented.

\section{II.2 Currency Unions in Latin America: A Selective Review}

Most studies on OCA in Latin America have analyzed whether the countries in the region satisfy the OCA criteria, or, more specifically, a subset of them. In this subsection I review some of the most important contributions to this literature

In an influential early paper, Bayoumi and Eichengreen (1994) used Vector Auto Regressions to construct series of supply and demand disturbances in three regions: 
Europe, Asia and the Americas. ${ }^{9}$ They then analyzed whether these disturbances were symmetrically distributed across the different countries in each of the regions. Their results indicate that correlations of both output and inflation disturbances were low in the Americas. Moreover, the groups of countries in the America's region that exhibited a somewhat higher degree of correlation did not correspond either to NAFTA or Mercosur. For instance, the group with the highest co-movements in output and prices was Brazil, Ecuador and Peru. The authors conclude that there is no evidence supporting the formation of a currency union involving Latin American countries - either among themselves, or with the U.S. or Canada. Eichengreen (1998) extended this work, and analyzed whether the countries of Mercosur - at the time formed by Argentina, Brazil, Paraguay and Uruguay - constituted an OCA. His analysis was triggered by the perceived instability between the bilateral exchange rate between the Brazilian and Argentine currencies. His empirical analysis concentrated on understanding the nature and consequences of exchange rate variability within the Mercosur nations. To do this he regressed alternative measures of exchange rate volatility on four of the "OCA criteria": synchronicity of output disturbances, commodity composition of trade, bilateral trade, and country size. He concludes that in the second half of the 1990s real exchange rate volatility in the Mercosur nations was significantly larger than what his model predicted. He argued, however, that a regional currency was not an effective option for reducing volatility; in his view the countries of Mercosur did not satisfy many of the OCA criteria.

Licandro Ferrando (2000) and Lavagna and Giambiagi (2000) also analyzed whether the countries of Mercosur satisfied (some of) the OCA criteria listed in our "Decalogue." Licandro Ferrado (2000) focuses mostly on one of the synchronicity of real shocks. He constructs measures of supply shocks for Mercosur, NAFTA and the EU and analyzes the extent to which these are correlated across countries. He concludes that the degree of correlation among Mercosur nations is significantly lower than that of EU nations. Shocks correlations among NAFTA countries are somewhat higher than in Mercosur. His conclusion is that Mercosur is far from satisfying the OCA criteria. Lavagna and Giambiagi (2000) take a somewhat different approach, and concentrate on macroeconomic convergence and political coordination. After analyzing historical data

9 The Americas include 13 nations, including those in NAFTA and Mercosur. 
for Argentina and Brazil, and simulating macroeconomic conditions, the authors concluded that in (late) 1998 the large countries of Mercosur were not ready for forming a monetary union.

Larrain and Tavares (2003) use data for South and Central American countries to analyze the extent to which some of the OCA criteria are satisfied. An important contribution of their paper is that the authors make a distinction between two types of currency unions: dollarization and regional currencies. They use an approach similar to that of Eichengreen (1998) and use regressions to analyze the determinants of real exchange rate volatility. They also analyze the degree of asymmetry (or lack of synchronization) of output shocks, the composition of exports, and the extent of bilateral trade. Based on their analysis they conclude that dollarization maybe an option for the Central American nations; neither dollarization nor a regional currency appears to be a good option for South America.

Horchreiter and Siklos (2002) considered both static and dynamic arguments in their investigation of the potential for currency unions in Latin America. These authors centered their analysis on the nature of aggregate shocks, fiscal policy, and business cycle synchronicity. They investigated whether a treatise in the nature of Maastricht would help the Latin American nations achieve macroeconomic convergence. Their conclusion was that "the LAC countries are not generally good candidates for monetary union." Berg, Borenztien and Mauro (2002) also analyze the OCA criteria for a large group of Latin American nations. They focus on: (a) the pattern of trade; (b) output growth comovements; (c) financial variables co-movement; (d) political coordination; and (e) credibility. They conclude that "an independent common currency does not appear to be warranted for Latin American countries," and that "there is no obvious case for dollarization."

In an extensive study, Hochreiter, Schmidt-Hebbel and Winckler (2002) analyzed Latin America's prospects for a currency union, from the perspective of the European experience. They make the important point that OCA criteria are dynamic, in the sense that countries that adopt a common currency tend to experience an improvement in some of the key OCA prerequisites, such as the volume of bilateral trade and the degree of financial synchronization. Based on the European experience, the authors emphasize the 
need to coordinate fiscal policy in OCA countries. They also discuss the importance of labor mobility and flexibility, and financial integration and supervision. These authors arrive to two conclusions: "The available evidence on the costs and benefits of abandoning national currencies suggest significantly less favorable conditions in LAC than in Europe." And, "[D]ollarization seems to be more feasible for smaller LAC economies." In a related paper, Kopits (2002) draws lessons from the new EU accession countries for Latin America, and concludes that in the absence of better macroeconomic policy coordination the Latin nations are not good candidates for a currency union.

Belke and Gros (2002) analyze the effects of exchange rate and interest rate volatility on macroeconomic outcomes in the countries of the Southern Cone. They conclude that higher volatility has negative effects on both employment and private investment. The authors, however, caution on the implications of these findings for the currency union debate; a complete analysis of the issue, they point out, would require investigating other OCA criteria, including the possibility of coordinating macroeconomic (and especially fiscal) policies.

The paper by Panizza, Stein and Talvi (2003) is one of the few that provides an explicit and complete cost-benefit analysis of the decision to join a currency union. They analyze whether it would pay off for the Central American nations to give up their currencies and unilaterally adopt the U.S. dollar as legal tender. ${ }^{10}$ They consider several benefits of dollarization, including lower real exchange rate volatility, increased credibility, reduced financial fragility, and a higher volume of intraregional trade. The main source of costs is the lost of monetary independence; the extent of these costs are related to the nature of real shocks, the degree of labor mobility, and the extent to which the monetary authorities are willing to use their independence (this is the "fear to float" issue). Their conclusion is that "several of the countries under study should give dollarization a serious consideration.” Edwards and Magendzo (2003, 2006) analyzed the overall world experience with dollarization. They use a variety of statistical techniques, including matching coefficients and treatment regressions. Their findings indicate that dollarized countries have not had a different real GDP growth experience

10 This, in fact, was done by El Salvador in 2001. 
than countries with a currency of their own. Inflation has been significantly lower in dollarized countries, while GDP volatility was larger in dollarized economies.

After recognizing the endogeneity of many of the OCA criteria, Calderón, Chong and Stein (2002) investigated the likely effects of adopting a common currency on Latin America's intraregional trade and business cycle synchronization. Their results suggest that, contrary to the findings by Frankel and Rose (1998) and Rose and Engel (2001) for the EU, the impact of a currency union on these two variables is rather small in the Latin American region.

Alesina, Barro and Terneyro (2002) use a very large data set to analyze the "best monetary anchor" for a number of countries; the alternative anchors considered are the US dollar, the euro, and the yen. Their analysis is based on the effects of monetary integration on trade, price volatility and output volatility. Their results suggest that there is an unambiguous "best anchor" for only a handful of Latin American nations: The Euro for Argentina, and the US dollar for Costa Rica and Honduras. However, the fact that for Mexico and Ecuador the Euro is the "best" anchor according to one of the criteria, casts doubts on this analysis. Tenreyro and Barro (2003) implement an instrumental variables approach to deal with the endogeneity of some of the OCA criteria. Their results indicate that sharing a common currency increases the volume of bilateral trade, increases the comovements of national price levels, and decrease the co-movement of national outputs.

Powell and Sturzenegger (2003) analyzed an often forgotten endogenous aspect of currency unions: the effects of a common currency on financial integration and country risk. They use an event study methodology to analyze whether a reduction in currency risk - something that, in their view, would automatically happen if a country unilaterally dollarizes - results in a decline country risk. Using European data they find that there is a positive (and causal) correlation between currency and country risk premia. However, the evidence for their group of Latin American countries is not as strong as the evidence for the European nations.

To summarize, most of the literature on (potential) currency unions in Latin America has focused on investigating whether the countries in the region - or a subgroup of countries - satisfy (some of) the traditional OCA criteria. Most of these papers have concluded that Latin America does not constitute an optimal currency union. The results 
discussed in this section also cast doubts on the desirability of subgroups of Latin American countries of joining a currency union.

\section{Monetary Unions and External Crises: An Empirical Analysis from a Latin}

\section{American Perspective}

In this and next section I analyze empirically issues related to monetary unions in Latin America. ${ }^{11}$ However, in contrast with most of the existing literature reviewed above, I don't ask whether countries satisfy some of the OCA criteria. Instead, I use a new large data set to investigate the international evidence on the effects of currency unions on economic performance. I focus on two aspects of performance that are particularly important for the Latin American nations: (a) the probability of facing external crises, in the form of either sudden stops of capital inflows, or large reversals of current account deficits. And, (b) the effects of different shocks on economic growth, under alternative exchange rate and monetary regimes, including currency unions. In this Section I deal with the first set of questions, while in Section IV I address the second set of issues.

\section{III.1 Sudden Stops and Current Account Reversals in Latin America}

Latin America's economic history has been characterized by recurrent and massive external crises. Large devaluations have rocked the economies of almost every country at one point or another during the last six decades. Many of these crises had their origins on large "sudden stops" of capital inflows, and/or were characterized by large and very rapid "current account deficits reversals.",

Table 2 presents tabulation data on the incidence of sudden stops for the period the period 1970-2001; Table 3 contains data on the incidence of current account reversals. In both Tables I have divided the sample in six groups of countries Advanced (industrial) countries, Latin America and Caribbean, Asia, Africa, Middle East and North Africa, and Eastern Europe. Each Table also includes a Pearson test for equality of incidence across groups of countries. I have defined a "sudden stop" episode

\footnotetext{
${ }^{11}$ In the empirical sections of this paper the "Latin American" countries include the countries that the International Monetary Fund groups in the Western Hemisphere region. These include Latin American and Caribbean nations.

${ }^{12}$ See, for example, Calvo and Talvi (2005) and Edwards (2004).
} 
as an abrupt and major reduction in capital inflows to a country that up to that time had been receiving large volumes of foreign capital. More specifically, I imposed the following requirements for an episode to qualify as a "sudden stop": (1) the country in question must have received an inflow of capital (relative to GDP) larger than its region's third quartile during the two years prior to the "sudden stop." And (2), net capital inflows must have declined by at least $5 \%$ of GDP in one year. ${ }^{13}$ On the other hand, a "current account reversal" - reversals, in short -- is defined as a reduction in the current account deficit of at least $4 \%$ of GDP in one year. ${ }^{14}$

As may be seen from Table 2, the global historical incidence of sudden stops has been $6.4 \%$. Different groups of countries, however, have experienced very different realities, with the incidence being highest in the Middle East (11.3\%) and lowest in the advanced nations (3.7\%). The Latin American nations have the second highest incidence of sudden stops, with almost $8 \%$ of all year-country observations.

The tabulation on current account reversals in Table 3 indicates that the aggregate incidence rate has been $12.8 \%$. As may be seen, Latin America has had one of the highest incidence of current account at 16\%; the advanced (industrial) countries have had the lowest incidence at $2.4 \% .^{15}$

From an analytical perspective sudden stops and current account reversals are highly related phenomena. There is no reason, however, for their relationship to be oneto-one. Indeed, because of changes in international reserves, it is possible that a country that suffers a sudden stop does not experience at the same time a current account reversal. An analysis of the global data indicates that for the complete sample (3,106 observations) $46.8 \%$ of countries subject to a sudden stop also faced a current account reversal. At the same time, $22.8 \%$ of those with reversals also experienced (in the same year) a sudden stop of capital inflows. The regional data show that joint incidence of reversals and

\footnotetext{
${ }^{13}$ In order to check for the robustness of the results, I also used two alternative definitions of sudden stops, which considered a reduction in inflows of 3 and 7 of GDP in one year. Due to space considerations, however, I don't report detailed results using these definitions.

${ }^{14}$ I also used an alternative definition. The qualitative nature of the results discussed below, were not affected by the precise definition of reversals or sudden stops. See Edwards (2004).

15 As pointed out above, the Latin American nations have also been subject to recurrent large devaluation crises. Of course, these are eliminated if a country becomes "dollarized." Independent currency unions eliminate bilateral devaluations in the member countries; it is still possible, of course, that the common currency suffers a major devaluation relative to a convertible currency. This was the case of the CFA Franc in January, 1994.
} 
"sudden stops" has been highest in Africa, where approximately 59.3\% of sudden stops happened at the same time as current account reversals, and in Latin America where 25\% of reversals coincided with sudden stops. For every one of the regions, as well as for the complete sample, the Pearson $\chi^{2}$ tests have very small p-values, indicating that the observed differences across rows and columns are significant. That is, these tests suggest that although there are observed differences across these phenomena, the two are statistically related. Interestingly, these results do not change significantly if different definitions of reversals and sudden stops are used, or if alternative configurations of lags and leads are considered.

\section{III.2 An Empirical Model}

A number of studies, including Edwards $(2002,2004)$ and Frankel and Cavallo (2004) have found that sudden stops and current account reversals are costly in terms of growth. Countries that experience either of these phenomena have gone through significant and rather large declines in the rate of GDP growth. An important question, and one that I address in this Section, is whether a country's exchange rate/monetary regime affects the probability of experiencing a sudden stop or a current reversal. In particular, I am interested in understanding whether countries that belong to monetary unions have had a lower probability of experiencing these phenomena. A positive answer to this question would be important for the Latin American nations, as it would provide them with an institutional arrangement that would help them reduce the incidence of these negative events. In other words, reducing the probability of sudden stops and/or current account reversals would constitute an additional "benefit" of currency unions, a benefit that should be taken into account when evaluating the net effects of abandoning the country's currency and joining a union.

In order to understand further the forces behind sudden stops and current account reversals, and to investigate the (potential) role of currency unions, I estimated a number of panel equations on the probability of experiencing these two penomena. The empirical model is given by equations (1) and (2): 


$$
\begin{aligned}
& \rho_{t j} \quad=\left\{\begin{array}{cc}
1, & \text { if } \rho_{t j}^{*}>0, \\
0, & \text { otherwise. }
\end{array}\right. \\
& \rho_{t j}^{*} \quad=\alpha \omega_{t j}+\varepsilon_{t j} .
\end{aligned}
$$

Variable $\rho_{j t}$ is a dummy variable that takes a value of one if country $\mathrm{j}$ in period $\mathrm{t}$ experienced a sudden stop (current account reversal), and zero if the country did not experience a sudden stop (current account reversal). According to equation (2), whether the country experiences a sudden stop (current account reversal) is assumed to be the result of an unobserved latent variable $\rho_{t j}^{*} \cdot \rho_{t j}^{*}$, in turn, is assumed to depend linearly on vector $\omega_{t j}$. The error term $\varepsilon_{t j}$ is given by given by a variance component model: $\varepsilon_{t j}=v_{j}+\mu_{t j} . \quad v_{j}$ is iid with zero mean and variance $\sigma_{v}^{2} ; \mu_{t j}$ is normally distributed with zero mean and variance $\sigma_{\mu}^{2}=1$. One of the $\omega_{t j}$ in equation (2) is a dummy variable that takes the value of one if during that year the country in question belonged to a currency union; that is, if the country in question was dollarized or if it was a member of an independent currency union. The data set used covers 187 countries, for the 1970-2001 period. Not every country has data for every year, however; the panel is unbalanced. See the Data Appendix for exact data definition and data sources.

In determining the specification of this probit model I followed the literature on external crises, and I included the following covariates: ${ }^{16}$ (a) The ratio of the current account deficit to GDP lagged one period. (b) A sudden stop dummy that takes the value of one if the country in question experienced a sudden stop in the previous year. (c) An index that measures the relative occurrence of sudden stops in the country's region (excluding the country itself) during that particular year. This variable captures the effect of "regional contagion." (d) The one-year lagged rate of growth of domestic credit. (e) The lagged ratio of the country's fiscal deficit relative to GDP. (f) The country's initial

\footnotetext{
${ }^{16}$ See, for example, Frankel and Rose (1996), Milesi-Ferreti and Razin (2000) and Edwards (2002).
} 
GDP per capita (in logs). And, (g) a dummy variable that takes the value of one if the country in question belongs to a currency union. This dummy is called $C U$. The coefficient of this variable is of particular interest in this analysis, since it captures the effect of currency unions on the probability of a country experiencing a reversal or a sudden stop. As is discussed below, in some of the regressions I interact the dummy variable CU with other regressors.

\section{III.3 Basic Results}

The results obtained from the estimation of this variance-component probit model for a sample of large countries are presented in Table $4 .{ }^{17}$ Columns A through C refer to the probability of a current account reversal; columns D through $\mathrm{F}$ are for a sudden stop of capital inflows. I first discuss the results for current account reversals. As may be seen, the vast majority of coefficients have the expected sign, and many of them are significant at conventional levels. The results may be summarized as follows: Larger (lagged) current account deficits increase the probability of a reversal, as does a (lagged) sudden stop of capital inflows. The results also support for the contagion hypothesis: the variable that measures the incidence of sudden stops in the county's region is significantly positive in all of the equations. There is also evidence that a faster rate of growth of domestic credit increases the probability of reversals. Countries with higher GDP per capita have a lower probability of a reversal (coefficient marginally significant in some regressions). Form the perspective of this paper, the most important result is that the coefficient of the currency union dummy is not significant in any of the regressions. In order to investigate whether $\mathrm{CU}$ affected the probability of a crises in an indirect way, I also included it interacted with other of the regressors. ${ }^{18}$ Once again, the coefficient was not significant. The last three columns in Table 4 present the result from the random effect probit estimates for sudden stops. Broadly speaking these results support those for current account reversals. The currency union indicator is never significant (although now some of the point estimates are positive). An increase in the (lagged) current account deficit increases the probability of a sudden stop, as does a

\footnotetext{
${ }^{17}$ Due to data availability, some of the countries/territories in Table 1 are not included in the regression analysis. Many of the very small countries don't have data on GDP or other key macroeconomic variables. ${ }^{18}$ It is important to notice, however, that in probit models the interpretation of interactive variables is different than in linear models.
} 
higher incidence of sudden stops in the region. A somewhat surprising result is that according to these results, with other things given, a higher "initial" level of GDP per capita increases the probability of a sudden stop.

To summarize, the results obtained from the random effect probit panel regressions indicate that currency union countries don't face a lower probability than countries that have a national currency, of facing either sudden stops or current account reversals. The next question, and one addressed in the Section that follows, is whether currency union countries are affected by external shocks - including reversals and sudden stops - in the same way than countries with a national currency.

\section{Monetary Unions and Economic Performance: An Empirical Analysis from a Latin American Perspective}

In this section I investigate whether belonging to a monetary union affects the way in which external shocks affect a county's rate of economic growth. As pointed out in Section II of this paper, one of the potential costs of monetary unions is that countries give up independent monetary policy. This means that exchange rate adjustments cannot be used as a way of absorbing external shocks, including terms of trade shocks, current account reversals and sudden stops. How large these costs actually are is an empirical issue. In principle, if the countries belonging to a currency union have wages and prices flexibly - one of the OCA criteria - this cost would be rather low. In this case external shocks can be accommodated through changes in (real) wages and in domestic relative prices.

The question of how to accommodate international terms of trade shocks is particularly important for the Latin American nations. Traditionally, the countries in the region have been subject to substantial volatility in terms of trade shocks. For the period 1970-2001, for example, the standard deviation of rate of change of the terms of trade was $16.9 \%$. For the same period terms of trade volatility for the advanced countries was only $6.5 \%$; it was $14.5 \%$ in Asia.

\section{IV.1 An Empirical Model}

The point of departure of the econometric analysis is a two-equation formulation for the dynamics of real GDP per capita growth of country $\mathrm{j}$ in period t. Equation (3) is 
the long run GDP growth equation; equation (4), on the other hand, captures the growth dynamics process.

$$
\begin{aligned}
& \tilde{g}_{t}=\alpha+x_{j} \beta+r_{j} \theta+\omega_{j} . \\
& \Delta g_{j t}=\lambda\left[\tilde{g}_{j}-g_{j t-1}\right]+\varphi \nu_{j t}+\mu_{j t}+\varepsilon_{j t} .
\end{aligned}
$$

$\tilde{g}_{j}$ is the long run rate of real per capita GDP growth in country $\mathrm{j} ; x_{j}$ is a vector of structural, institutional and policy variables that determine long run growth; $r_{j}$ is a vector of regional dummies; $\alpha, \beta$ and $\theta$ are parameters, and $\omega_{j}$ is an error term assumed to be heteroskedastic. In equation (3), $g_{j t}$ is the rate of growth of per capita GDP in country $\mathrm{j}$ in period t. The terms $v_{j t}$ and $u_{j t}$ are shocks, assumed to have zero mean and finite variance. More specifically, $v_{j t}$ is assumed to be an external terms of trade shock, while $u_{j t}$ captures other shocks, including current account reversals or sudden stops. $\mathcal{E}_{j t}$ is an error term, which is assumed to have a variance component form, and $\lambda, \varphi$, and $\gamma$ are parameters that determine the particular characteristics of the growth process. Equation (4) has the form of an equilibrium correction model and states that the actual rate of growth in period $t$ will deviate from the long run rate of growth due to the existence of three types of shocks: $v_{t j}, u_{t j}$ and $\xi_{t j}$. Over time, however, the actual rate of growth will tend to converge towards it long run value, with the rate of convergence given by $\lambda$. Parameter $\varphi$, in equation (4), is expected to be positive, indicating that an improvement in the terms of trade will result in a (temporary) acceleration in the rate of growth, and that negative terms of trade shock are expected to have a negative effect on $g_{j t} \cdot{ }^{19}$ If, as previous work has found, current account reversals and/or sudden stops have a negative effect on growth, we would expect the coefficient $\gamma$ to be significantly negative.

In terms of the subject of this paper, the main interest is whether the coefficients of the external shocks $v_{t j}$ and $u_{t j}$ are different for currency union countries and countries

19 See Edwards and Levy Yeyati (2005) for details. 
with a currency of their own. If giving up monetary independence because of membership in a currency union is costly, we would expect $\varphi$ to be larger for currency union countries, and $\gamma$ to be more negative in currency union countries than in countries with a currency of their own. That is, in the absence of monetary independence and exchange rate flexibility, external shocks would be amplified. If, on the contrary, the loss of monetary independence is not costly, these coefficients would be the same - or very similar - across the two groups of countries.

Equations (3) - (4) were estimated using a two-step procedure. In the first step I estimate the long run growth equation (3) using a cross-country data set. These data are averages for 1970-2001, and the estimation makes a correction for heteroskedasticity. These first stage estimates are then used to generate long-run predicted growth rates to replace $\widetilde{g}_{j}$ in the equilibrium error correction model (4). In the second step, I estimated equation (4) using GLS for unbalanced panels; I used both random effects and fixed effects estimation procedures. $^{20}$ The data set includes 157 countries, for the 1970-2001 period; not every country has data for every year, however. See the Data Appendix for exact data definition and data sources. In Sub-Section IV.3 I present some extensions.

\section{IV.2 Basic Results}

In estimating equation (3) for long-run per capita growth, I followed the standard literature on growth, as summarized by Barro and Sala-I-Martin (1995), Sachs and Warner (1995) and Dollar (1992) among others. I assume that the rate of growth of GDP $\left(\tilde{g}_{j}\right)$ depends on a number of structural, policy and social variables. More specifically, I include the following covariates: the log of initial GDP per capita; the investment ratio; the coverage of secondary education, as a proxy for human capital; an index of the degree of openness of the economy; the ratio of government consumption relative to GDP; and regional dummies. The results obtained from these first-step estimates are not reported due to space considerations.

In Table 5 I present the results from the second step estimation of the growth dynamics equation (4), when random effects were used. The Table has six columns: the first two contain the results for all countries with a national currency (independently of

\footnotetext{
${ }^{20}$ Due to space considerations, only the random effect results are reported.
} 
their exchange rate and monetary regime). The next two columns contain the results for countries with a currency of their own and flexible exchange rate regimes. Finally, the last two columns contain the results for currency union countries. ${ }^{21}$

As may be seen, the results are quite interesting. The estimated coefficient of the growth gap is, as expected, positive, significant, and smaller than one. The point estimates are on the high side -- between 0.79 and 0.92 --, suggesting that, on average, deviations between long run and actual growth get eliminated rather quickly. Also, as expected, the estimated coefficients of the terms of trade shock are always positive, and statistically significant, indicating that an improvement (deterioration) in the terms of trade results in an acceleration (de-acceleration) in the rate of growth of real per capita GDP in our three samples. The coefficients of the current account reversals and the sudden stops variables are significantly negative, in the regressions for the complete sample (Columns A and B) and in those for the currency union countries (Columns E and F), indicating that these shocks have been associated with a deceleration of growth. Interestingly, these coefficients are not significant for the flexible exchange rate countries, suggesting that this group has been able to accommodate these external shocks without experiencing a significant decline in GDP growth. From the perspective of this paper, what is particularly important is that the point estimates of the shock-related coefficients are larger for the currency union countries than for the two samples of nations with a currency of their own. Consider, for example, the specification in columns A, C and E. The point estimates of the terms of trade shock are 0.07 for all countries with a national currency, 0.03 for the flexible exchange rate countries, and 0.10 for the currency union countries. The computation t-tests indicate that these coefficients are statistically different across equations; the values of these t-tests are 7.8 for the comparison of currency union and flexible countries, and 3.81 for the comparison between currency union and all countries. For the specifications in Columns A, B and C the point estimates of the current account reversal variable are also larger in absolute terms for the currency union countries $(-2.30)$, than for the flexible rates countries $(-0.47$ and non significant), and the all countries with a currency group (-0.74).

\footnotetext{
${ }^{21}$ I used the Levy-Yeyati and Stuzenegger (2003b) de facto exchange rate regimes classification.
} 
Overall, then, the results reported in Table 5 indicate that countries that belong to a currency union had suffered a greater impact from external shocks than countries with a national currency. The difference in the effects of external shocks is particularly large when the currency union countries are compared with nations that have had flexible exchange rates. This result is particularly important, since it is precisely under flexible exchange rates that countries are able to exercise fully an independent monetary policy.

\section{IV.3 Instrumental Variables Estimates and Other Extensions}

Instrumental Variables: Some of the results presented above may be subject to endogeneity problems. This is particularly the case of the specification that includes the current account reversals as a regressor. In this section I present results obtained when instrumental variables random effect regressions for unbalanced panels were estimated. The results obtained are presented in Table 6, for the same three samples: all countries with a national currency, flexible exchange rate nations and currency union countries. In deciding which instruments to use, I took into account the results in the preceding section on the probability of a country experiencing a reversal. The following instruments were used: lagged changes in the international terms of trade, lagged current account balance, lagged indicator for occurrence of sudden stop during the previous year, a lagged index of occurrence of sudden stops in the country's group or region, lagged international reserves over GDP ratio, lagged rate of growth of domestic credit. As may be seen from Table 6, the results tend to confirm the findings reported in Table 5. The estimated coefficients for both external shocks variables - changes in international terms of trade and current account reversals - are significantly larger for the currency union countries than for the two samples of countries with a national currency.

Asymmetric Terms of Trade Shocks: The results discussed above were obtained under the assumption that positive and negative terms of trade shock have a symmetric effect on the dynamics of growth. This needs not be the case, however. ${ }^{22}$ In order to investigate this issue re-estimated equation (4) replacing the terms of trade term by two; a positive terms of trade shock and a negative terms of trade shock. The results obtained indicate that the effects of terms of trade shocks are asymmetric, with negative terms of trade shocks having a larger (negative) effect on growth than positive terms of trade

\footnotetext{
${ }^{22}$ See Edwards and Levy-Yeyati (2005) for a discussion of this issue.
} 
shocks. The results obtained for the specification with the reversals shock are presented in Table 7. The difference in the point estimate for the positive and negative terms of trade shock are particularly large for the currency union countries. Overall, these estimates, once again, confirm our previous findings, in the sense that external shocks have a larger effect on growth in currency union countries than in countries with a currency of their own.

Alternative Measures of External Shocks: The results reported above were obtained using three alternative measures of external shocks: terms of trade changes, current account reversals, and sudden stops of capital inflows. As pointed out in Section III of this paper, there is a close connection between current account reversals and sudden stops. An important question, thus, is the effect on economic activity of crises that are characterized by both current account reversals and sudden stops. ${ }^{23}$ The results obtained, available upon request, tend to confirm those reported in Tables 5 through 7: the (negative) effects of external crises on GDP growth tend to be more severe currency union countries than in countries with a currency of their own and flexible exchange rates.

\section{Concluding Remarks}

Recently debates on the merits of currency unions have intensified. At the light of the Euro experience a number of authors have argued that some countries -in particular small emerging countries - would benefit by joining a currency union. Most studies on the subject have analyzed if specific groups of countries satisfy the Optimal Currency Areas criteria. In this paper I have taken an alternative approach from that of most works on the subject. Instead of analyzing whether the Latin American countries satisfy the traditional OCA criteria, such as facing similar external shocks across countries, I have analyzed the empirical evidence on the economic performance of countries "without a currency of their own," and I interpret these results from the perspective of the Latin American nations. The empirical analysis presented in this paper was divided in two parts. First, an analysis of the determinants of the probability of a country being subject to: (a) "sudden stops" of capital inflows; and/or (b) "current account reversals." Both of these

\footnotetext{
${ }^{23}$ I am grateful to Klaus Schmidt-Hebbel for suggesting this line of analysis.
} 
are important questions, since the Latin American nations have traditionally been subject to significant fluctuations in capital flows, and have experienced a large number of current account crises. The results obtained from this analysis suggest that belonging to a currency union has not lowered the probability of experiencing either a sudden stop or a current account reversal. In the second empirical part of this study, I analyzed the ability of monetary union countries to accommodate three types of external shocks: (a) terms of trade shocks; (b) sudden stops of capital inflows; and (c) current account reversals. The results obtained - and reported in Section IV of the paper - indicate that the (negative) effects of external crises on GDP growth have tended to be more severe currency union countries than in countries with a currency of their own and flexible exchange rates. These results provide valuable additional information for the debate on the costs and benefits of countries giving up their national currencies and joining a currency union. It is important to notice, however, that the results reported here should be interpreted with some caution. The reason for this is that the number of Currency Union countries and years in the data set is limited. There are only three years of the Euro, and most non-euro $\mathrm{CU}$ countries are rather small. Additional data in the years to come will make the empirical analysis of performance in Currency Union countries more reliable. 
Table 1

\section{Currency Unions}

\begin{tabular}{|c|c|}
\hline AUSTRALIA & CHINA \\
\hline Christmas Island (dependency) & $\overline{\text { Macau (dependency) }}$ \\
\hline \multicolumn{2}{|l|}{ Cocos (Keeling) Island (dependency) } \\
\hline Norfolk Island (dependency) & $\underline{\text { MOROCCO }}$ \\
\hline Kiribati & Western Sahara \\
\hline \multicolumn{2}{|l|}{ Nauru } \\
\hline Tuvalu & $\frac{\text { NETHERLANDS }}{\text { Netherlands Antilles (dependency) }}$ \\
\hline DENMARK & Aruba (dependency) \\
\hline \multicolumn{2}{|l|}{$\overline{\text { Faroe Islands (dependency) }}$} \\
\hline Greenland (dependency) & $\frac{\text { NEW ZEALAND }}{\text { Niue (dependency) }}$ \\
\hline$\underline{\text { ECCA }}$ & Tokelau (dependency) \\
\hline$\overline{\text { Anguilla (dependency of UK) }}$ & Pitcairn Island (dependency of UK) \\
\hline \multicolumn{2}{|l|}{ Antigua and Barbuda } \\
\hline Dominica & $\underline{\text { SINGAPORE }}$ \\
\hline Grenada & Brunei \\
\hline \multicolumn{2}{|l|}{ Montserrat (dependency of UK) } \\
\hline Saint Kitts and Nevis & $\underline{\text { SOUTH AFRICA }}$ \\
\hline Saint Lucia & Lesotho \\
\hline Saint Vincent and the Grenadines & Namibia \\
\hline FRANCE & $\underline{\text { UNITED KINGDOM }}$ \\
\hline$\overline{\text { French Guiana (dependency) }}$ & 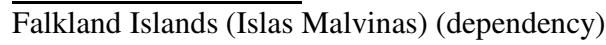 \\
\hline French Polynesia (dependency) & Gibraltar (dependency) \\
\hline Guadeloupe (dependency) & Saint Helena (dependency) \\
\hline Martinique (dependency) & British Indian Ocean Territory (dependency) \\
\hline \multicolumn{2}{|l|}{ New Caledonia (dependency) } \\
\hline Reunion (dependency) & $\underline{\mathbf{U S A}}$ \\
\hline Saint Pierre and Miquelon (dependency) & Northern Mariana Islands (dependency) \\
\hline Wallis and Futuna (dependency) & Bermuda (dependency of UK) \\
\hline Andorra & $\begin{array}{l}\text { British Virgin Islands (dependency of UK) } \\
\text { Cayman Islands (dependency of UK) }\end{array}$ \\
\hline SPAIN & Turks and Caicos Islands (dependency of UK) \\
\hline Andorra & $\begin{array}{l}\text { Bahamas, The } \\
\text { Barbados }\end{array}$ \\
\hline BELGIUM & Belize \\
\hline Luxembourg & $\begin{array}{l}\text { Ecuador (since 2000) } \\
\text { Guatemala }\end{array}$ \\
\hline$\underline{\text { CFA }}$ & Liberia \\
\hline$\overline{\text { Benin }}$ & Marshall Islands \\
\hline Burkina Fasso & Micronesia, Federated States of \\
\hline Cameroon & Palau \\
\hline Central African Republic & Panama \\
\hline \multicolumn{2}{|l|}{ Chad } \\
\hline \multicolumn{2}{|l|}{ Congo, Republic of the } \\
\hline \multicolumn{2}{|l|}{ Cote d'Ivoire } \\
\hline \multicolumn{2}{|l|}{ Equatorial Guinea } \\
\hline \multicolumn{2}{|l|}{ Gabon } \\
\hline \multicolumn{2}{|l|}{ Guinea-Bissau } \\
\hline \multicolumn{2}{|l|}{ Mali } \\
\hline \multicolumn{2}{|l|}{ Niger } \\
\hline \multicolumn{2}{|l|}{ Senegal } \\
\hline Togo & \\
\hline
\end{tabular}

Source: Refers to the year 1996. Cabasson (2003) 
Table 2

Incidence of Sudden Stops: 1970-2001

\begin{tabular}{l|cc}
\hline Region & No sudden stop & Sudden stop \\
\hline & & \\
Industrial countries & 96.3 & 3.7 \\
Latin American and Caribbean & 92.2 & 7.8 \\
Asia & 94.9 & 5.1 \\
Africa & 93.4 & 6.6 \\
Middle East & 88.7 & 11.3 \\
Eastern Europe & 93.7 & 6.4 \\
& & \\
Total & 93.6 & 6.4 \\
$\quad$ & \\
$\quad$ Observations & 2,943 & \\
$\quad$ Pearson & & \\
$\quad$ Uncorrected chi2 (5) & 18.84 & \\
$\quad$ Design-based F(5, 14710) & 3.76 & \\
$\quad$ P-value & 0.002 & \\
\hline
\end{tabular}

Table 3

Incidence of Current Account Reversals: 1972-2001

\begin{tabular}{l|cc}
\hline Region & No Reversal & Reversal \\
\hline & & \\
Industrial countries & 97.6 & 2.4 \\
Latin American and Caribbean & 84.0 & 16.0 \\
Asia & 87.9 & 12.1 \\
Africa & 83.4 & 16.1 \\
Middle East & 84.0 & 16.0 \\
Eastern Europe & 85.0 & 15.0 \\
& & \\
Total & 87.2 & 12.8 \\
$\quad$ & \\
$\quad$ Observations & 2,975 & \\
Pearson & & \\
$\quad$ Uncorrected chi2 (5) & 77.88 & \\
$\quad$ Design-based F(5, 14870) & 15.57 & \\
$\quad$ P-value & 0.000 & \\
\hline
\end{tabular}


Table 4

Determinants of Current Account Reversals and Sudden Stops

Random Effects Probit Regressions

\begin{tabular}{|c|c|c|c|c|c|c|}
\hline \multirow[t]{2}{*}{ Variable } & \multicolumn{3}{|c|}{ Current Account Reversals } & \multicolumn{3}{|c|}{ Sudden Stops } \\
\hline & (A) & (B) & $(C)$ & (D) & $(E)$ & $(F)$ \\
\hline Current-Account deficit to GDP & $\begin{array}{c}0.10 \\
(10.21)^{* * *}\end{array}$ & $\begin{array}{c}0.09 \\
(11.99)^{* * *}\end{array}$ & $\begin{array}{l}-- \\
--\end{array}$ & $\begin{array}{c}0.07 \\
(7.16)^{* * * *}\end{array}$ & $\begin{array}{c}0.07 \\
(9.04) * * *\end{array}$ & $\begin{array}{l}-- \\
--\end{array}$ \\
\hline Sudden stop & 0.39 & 0.39 & -- & -- & -- & -- \\
\hline & $(2.04)^{* *}$ & $(2.48)^{* *}$ & -- & -- & -- & -- \\
\hline Sudden stops in region & $\begin{array}{c}2.06 \\
(4.16)^{* * *}\end{array}$ & $\begin{array}{c}2.25 \\
(5.25) * * *\end{array}$ & $\begin{array}{l}-- \\
--\end{array}$ & $\begin{array}{c}3.96 \\
(6.71)^{* * * *}\end{array}$ & $\begin{array}{c}4.47 \\
(8.37)^{* * *}\end{array}$ & $\begin{array}{l}-- \\
--\end{array}$ \\
\hline Domestic credit growth & $\begin{array}{l}0.0002 \\
(1.78)^{*}\end{array}$ & $\begin{array}{l}0.0002 \\
(1.75)^{*}\end{array}$ & $\begin{array}{l}-- \\
--\end{array}$ & $\begin{array}{c}-0.0005 \\
(1.11)\end{array}$ & $\begin{array}{c}-0.0000 \\
(0.45)\end{array}$ & $\begin{array}{l}-- \\
--\end{array}$ \\
\hline Fiscal deficit to GDP & $\begin{array}{l}-0.002 \\
(0.22)\end{array}$ & $\begin{array}{l}-- \\
--\end{array}$ & $\begin{array}{l}-- \\
--\end{array}$ & $\begin{array}{l}-0.01 \\
(0.85)\end{array}$ & $\begin{array}{l}-- \\
--\end{array}$ & $\begin{array}{l}-- \\
--\end{array}$ \\
\hline Initial GDP per capita & $\begin{array}{c}-0.08 \\
(1.67)^{*}\end{array}$ & $\begin{array}{l}-0.04 \\
(0.86)\end{array}$ & $\begin{array}{l}-- \\
--\end{array}$ & $\begin{array}{c}0.23 \\
(3.82) * * *\end{array}$ & $\begin{array}{c}0.25 \\
(4.22)^{* * * *}\end{array}$ & $\begin{array}{l}-- \\
--\end{array}$ \\
\hline $\mathrm{CU}$ & $\begin{array}{l}-- \\
--\end{array}$ & $\begin{array}{l}-0.02 \\
(0.14)\end{array}$ & $\begin{array}{c}0.17 \\
(1.26)\end{array}$ & $\begin{array}{l}-- \\
--\end{array}$ & $\begin{array}{c}0.20 \\
(0.83)\end{array}$ & $\begin{array}{c}0.26 \\
(1.27)\end{array}$ \\
\hline $\begin{array}{l}\text { Observations } \\
\text { Countries }\end{array}$ & $\begin{array}{c}1515 \\
95\end{array}$ & $\begin{array}{c}1886 \\
118\end{array}$ & $\begin{array}{c}2653 \\
143\end{array}$ & $\begin{array}{c}1515 \\
95\end{array}$ & $\begin{array}{c}1954 \\
119\end{array}$ & $\begin{array}{c}2238 \\
127\end{array}$ \\
\hline
\end{tabular}

Absolute value of $\mathrm{z}$ statistics is reported in parentheses; All regressors are one-period lagged; constant term is included, but not reported. $* * *$ significant at $1 \%$; ** significant at 5\%; * significant at $10 \%$; 
Table 5

Current Account Reversals, Sudden Stops and Growth

Random Effects GLS Regressions

\begin{tabular}{|c|c|c|c|c|c|c|}
\hline \multirow[t]{2}{*}{ Variable } & \multicolumn{2}{|c|}{$\begin{array}{l}\text { Countries with national } \\
\text { currency }\end{array}$} & \multicolumn{2}{|c|}{$\begin{array}{c}\text { Countries with national } \\
\text { currency and flexible } \\
\text { exchange rate }\end{array}$} & \multicolumn{2}{|c|}{$\begin{array}{l}\text { Countries with currency } \\
\text { union }\end{array}$} \\
\hline & (A) & (B) & (C) & (D) & (E) & (F) \\
\hline Growth gap & $\begin{array}{c}0.79 \\
(38.18)^{* * *}\end{array}$ & $\begin{array}{c}0.80 \\
(39.37)^{* * *}\end{array}$ & $\begin{array}{c}0.87 \\
(20.97)^{* * *}\end{array}$ & $\begin{array}{c}0.84 \\
(21.61)^{* * *}\end{array}$ & $\begin{array}{c}0.84 \\
(12.58)^{* * *}\end{array}$ & $\begin{array}{c}0.92 \\
(11.09)^{* * *}\end{array}$ \\
\hline Change in terms of trade & $\begin{array}{c}0.07 \\
(11.22)^{* * *}\end{array}$ & $\begin{array}{c}0.07 \\
(11.08)^{* * *}\end{array}$ & $\begin{array}{c}0.03 \\
(2.69)^{* * *}\end{array}$ & $\begin{array}{c}0.06 \\
(4.50)^{* * *}\end{array}$ & $\begin{array}{c}0.10 \\
(4.59)^{* * *}\end{array}$ & $\begin{array}{c}0.09 \\
(4.25)^{* * *}\end{array}$ \\
\hline Current account reversal & $\begin{array}{c}-0.74 \\
(4.16)^{* * *}\end{array}$ & $\begin{array}{l}-- \\
--\end{array}$ & $\begin{array}{l}-0.47 \\
(0.63)\end{array}$ & $\begin{array}{l}-- \\
--\end{array}$ & $\begin{array}{c}-2.30 \\
(1.98)^{* *}\end{array}$ & $\begin{array}{l}-- \\
--\end{array}$ \\
\hline Sudden stop & -- & $\begin{array}{l}-0.28 \\
(2.74)^{* * *}\end{array}$ & -- & $\begin{array}{c}0.21 \\
(0.25)\end{array}$ & -- & $\begin{array}{l}-1.79 * \\
(1.62)\end{array}$ \\
\hline
\end{tabular}

Absolute value of $\mathrm{z}$ statistics is reported in parentheses; constant term is included, but not reported. $* * *$ significant at $1 \%$; ** significant at 5\%; $*$ significant at $10 \%$; 
Table 6

Current Account Reversals, Sudden Stops and Growth

IV Regressions

\begin{tabular}{l|ccc}
\hline Variable & $\begin{array}{c}\text { Countries with } \\
\text { national currency }\end{array}$ & $\begin{array}{c}\text { Countries with } \\
\text { national currency } \\
\text { and flexible } \\
\text { exchange rate }\end{array}$ & $\begin{array}{c}\text { Countries } \\
\text { with currency } \\
\text { union }\end{array}$ \\
\hline Growth gap & 0.78 & 0.78 & 0.94 \\
Change in terms of trade & $(31.67)^{* * *}$ & $(16.33)^{* * *}$ & $(9.42)^{* * *}$ \\
Current account reversal & 0.06 & 0.06 & 0.12 \\
& $(8.22)^{* * *}$ & $(3.67)^{* * *}$ & $(3.70)^{* * *}$ \\
Observations & -3.27 & -5.11 & $-9.48^{*}$ \\
Countries & $(2.42)^{* *}$ & $(1.27)$ & $(1.62)$ \\
\hline
\end{tabular}

Absolute value of $\mathrm{z}$ statistics is reported in parentheses; constant term is included, but not reported. *** significant at $1 \%$; ** significant at $5 \%$; * significant at $10 \%$; 
$\underline{\text { Table } 7}$

Asymmetric Terms of Trade Shocks and Growth

\section{$\underline{\text { Random Effects GLS Regressions }}$}

\begin{tabular}{l|ccc}
\hline Variable & $\begin{array}{c}\text { Countries with } \\
\text { national currency }\end{array}$ & $\begin{array}{c}\text { Countries with } \\
\text { national currency } \\
\text { and flexible } \\
\text { exchange rate }\end{array}$ & $\begin{array}{c}\text { Countries with } \\
\text { currency union }\end{array}$ \\
\hline Growth gap & 0.79 & 0.87 & 0.84 \\
Current account reversal & $(38.18)^{* * * *}$ & $(20.92)^{* * *}$ & $(12.56)^{* * *}$ \\
Positive change in terms of trade & -0.69 & -0.55 & -2.11 \\
& $(1.95)^{*}$ & $(0.72)$ & $(1.80)^{*}$ \\
Negative change in terms of trade & 0.06 & 0.04 & 0.07 \\
& $(5.80)^{* * *}$ & $(2.35)^{* * *}$ & $(1.89)^{*}$ \\
Observations & 0.09 & 0.02 & 0.13 \\
Countries & $(7.77)^{* * *}$ & $(0.51)$ & $(3.31)^{* * *}$ \\
\hline
\end{tabular}

Absolute value of $\mathrm{z}$ statistics is reported in parentheses; constant term is included, but not reported. *** significant at 1\%; ** significant at 5\%; * significant at 10\%; 


\section{REFERENCES}

Alesina, A. F., Barro, R. J. and S. Tenreyro. 2002. "Optimal Currency Areas," Harvard Institute Research Working Paper No 1958.

Barro, R., Sala-I-Martin, X., 1995. Economic Growth. McGraw Hill, New York.

Bayoumi, T. 1994. “A Formal Model of Optimum Currency Areas. IMF Staff Papers 41: 537-558.

Bayoumi, T. and B. Eichengreen. 1994. "One Money or Many? Analyzing the Prospects for Monetary Unification in Various Parts of the World," Studies in International Finance, No. 76, Princeton, NJ: Princeton

1997. "Ever Closer To Heaven? An Optimum-Currency-

Area Index for European Countries," European Economic Review, 41(3-5): 761-770.

Belke, A. and D. Gros. 2002. "Monetary Integration in the Southern Cone," The North American Journal of Economics and Finance, 13(3): 323-349.

Berg, A., Borensztein, E. and P. Mauro. 2002. "An Evaluation of Monetary Regime Options for Latin America," The North American Journal of Economics and Finance, 13(3): 213-235.

Cabasson, D. 2003. "Survey about Monetary Unions,", mimeo.

Calderón, C., Chong, A. and E. Stein. 2002. "Trade Intensity and Business Cycle Synchronization: Are Developing Countries Any Different?," Working Papers Central Bank of Chile 195, Central Bank of Chile.

Calvo, G. A. and E. Talvi. 2005. "Sudden Stop, Financial Factors and Economic Collapse in Latin America: Learning from Argentina and Chile," NBER Working Paper, No. 11153.

De Grauwe, P. 2001. The Political Economy of Monetary Union. Elgar Reference Collection. International Library of Critical Writings in Economics, vol. 134.

Cheltenham, U.K. and Northampton, Mass.: Elgar.

Dollar, D., 1992. "Outward-Oriented Developing Economies Really Do Grow More Rapidly: Evidence from 95 LDCs, 1976-1985," Economic Development and Cultural Change, 40(3): 523-44.

Dornbusch, R. 2001. "Fewer Monies, Better Monies," American Economic Review, American Economic Association, vol. 91(2), pages 238-242. 
Edwards, S. 2004. "Thirty Years of Current Account Imbalances, Current Account Reversals and Sudden Stops," IMF Staff Papers, Vol. 61, Special Issue: 1-49.

2002. "Does the Current Account Matter?", in S. Edwards and J. A. Frankel (Eds.): Preventing Currency Crises in Emerging Markets, The University of Chicago Press.

1999. "The Choice of Exchange Rate Regime in Developing and

Middle Income Countries," in Takatoshi Ito and Anne O. Krueger, eds., Changes in Exchange Rates in Rapidly Developing Countries: Theory, Practice, and Policy Issues, 9-23, NBER-East Asia Seminar on Economics, vol. 7., Chicago and London: University of Chicago Press.

Edwards, S. and E. Levy Yeyati. 2005. "Flexible Exchange Rates as Shock Absorbers," European Economic Review, 49(8): 2079-2105.

Edwards, S. and I. I. Magendzo. 2006. "Strict Dollarization and Economic Performance: An Empirical Investigation," Journal of Money, Credit, and Banking, forthcoming.

. 2003. "A Currency of One's Own? An Empirical Investigation on Dollarization and Independent Currency Unions," NBER Working Paper No. 9514.

Eichengreen, B. 1998. "Does Mercosur Need a Single Currency," NBER Working Papers: 6821.

G.F. Ferrando. 2000. "¿Un Área Monetaria para el Mercosur?," in J. Carrera and F. Sturzenegger (Eds.): Coordinación de Políticas Macroeconómicas en el MERCOSUR, Fondo de Cultura Económica México, D.F.

Frankel, J.A. and E. A. Cavallo. 2004. "Does Openness to Trade Make Countries More Vulnerable to Sudden Stops, Or Less? Using Gravity to Establish Causality," NBER Working Paper, No. 10957.

Frankel, J.A. and A.K. Rose. 1998. "The Endogeneity of the Optimum Currency Area Criterion," The Economic Journal, 108(449):1009-1025.

.1996. "Currency Crashes in Emerging Markets: An

Empirical Treatment, ” Journal of International Economics, 41(3-4): 351-366

2002. "An Estimate of the Effect of Common Currencies on Trade and Income," Quarterly Journal of Economics 117(2): 437-66.

Hochreiter, E. and P. L. Siklos. 2002. "Alternative Exchange-Rate Regimes: The Options for Latin America," The North American Journal of Economics and Finance, 13(3): 195211. 
Hochreiter, E., K. Schmidt-Hebbel and G. Winckler. 2002. "Monetary Union: European Lessons, Latin American Prospects," The North American Journal of Economics and Finance, 13(3): 297-321

Kenen, P. B. 1969. "The Theory of Optimum Currency Areas: An Eclectic View” in Mundell, R.A. and A.K. Swoboda (eds.) Monetary Problems of the International Economy, Chicago: University Press.

Kopits, G. 2002. "Central European EU Accession and Latin American Integration: Mutual Lessons in Macroeconomic Policy Design," The North American Journal of Economics and Finance, 13(3): 253-277.

Larrain, F. and J. Tavares. 2003. "Regional Curremcies versus Dollarization: Option for Asia and the Americas," Policy Reform, 6(1): 35-49.

Lavagna, R. and F. Giambiagi. 2000. "Hacia la Creación de una Moneda Común: Una Propuesta de Convergencia Coordinada de Políticas Macroeconómica en el MERCOSUR", in J. Carrera and F. Sturzenegger (Eds.): Coordinación de Políticas Macroeconómicas en el MERCOSUR, Fondo de Cultura Económica México, D.F.

Levy Yeyati, E. and F. Sturzenegger. 2003. "Dollarization: A Primer," in Levy Yeyati E. and F. Sturzenegger (eds): Dollarization, Cambridge and London: MIT Press: 1-51 . 2003b. "To Float or to Fix: Evidence on the Impact of Exchange Rate Regimes on Growth," American Economic Review 93 (4): 1178-89.

McKinnon, R. I. 1963. “Optimum Currency Areas” American Economic Review 53: 717725 .

Milesi-Ferretti, G. M. and A. Razin. 2000. "Current Account Reversals and Currency Crises: Empirical Regularities," in P. Krugman (Ed.): Currency Crises, U. of Chicago Press.

Mongelli F. P. 2002. "New Views on the Optimal Currency Area Theory: What is EMU Telling Us?," European Central Bank Working Papers No. 138.I

Muhleman, M. 1985. Monetary Systems of the World. New York: Charles Nicholl.

Mundell, R. A. 1961. “A Theory of Optimum Currency Areas," American Economic Review 51(4): 657-65.

Panizza, H., Stein, E. and E. Talvi. 2003. “Assessing Dollarization: An Application to Central American and Caribbean Countries", in E. Levy-Yeyati and F. Sturzenneger (eds.) Dollarization, Cambridge and London: MIT Press: MIT Press 
Powell, A. and F. Sturzenegger. 2003. "Dollarization: The Link between Devaluation and Default Risk," in Levy Yeyati E. and F. Sturzenegger (Eds.): Dollarization, Cambridge and London: MIT Press: 201-236

Rose A. K. 2000. "One Money, One Market: Estimating the Effect of Common Currencies on Trade", Economic Policy, 15 (30): 7-46.

Rose, A. K and Ch. Engel 2002. "Currency Unions and International Integration," Journal of Money, Credit and Banking, 34(4): 1067-89.

Rose A K. and van Wincoop E. 2001. "National Money as a Barrier to International Trade: The Real Case for Currency Union”, American Economic Review 91(2): 386-390.

Sachs, J.D., Warner, A.M., 1995. "Economic Reform and the Process of Global Integration," Brookings Papers on Economic Activity (1), 1-118.

Tavlas, G.S. 1993. "The 'New' Theory of Optimum Currency Areas.” World Economy 16: 663-85. . 1992. "Vehicle Currencies," in P. Newman, M. Milgate and J Eatwell (Eds): The New Palgrave Dictionary of Money and Finance, 3: 754-777, London: Mc Millan. . 1991. "On The International Use of Currencies: The Case of the Deutsche Mark," Essays in International Finance, No. 181. Princeton, N.J.: International Finance Section, Princeton University

Tenreyro, S. and R. J. Barro. 2003. "Economic Effects of Currency Unions," NBER Working Paper, No 9435

Yañez, E., A.E. Bunge and G. Subercaseaux, "Hacia una Unión Aduanera y Monetaria en América Latina," Imprenta la Nación, Santiago de Chile, 1926 